Calandridae.

Calandra remotepunctata Gyll. Cossonus platalea Say.

Scolytidae.

Pityophthorus pullus Zimm.
Coccotrypes jalappae Letz. Detroit. ['Schwarz.]

Tomicus calligraphus Germ. Pine regions. [Cook.]

Dendroctonus terebrans Oliv. Pine regions. [Cook.]

\title{
A SHORT CHAPTER IN THE HISTORY OF THE CYNIPIDOUS GALL-FLIES.
}

BY HOMER FRANKLIN BASSETT; WATERBURY, CT.

It was reasonable to suppose that when that most interesting field of research into the life history of the gall insects that relates to their agamic reproduction had been opened, some one or more of our young entomologists would have entered upon the investigations that were necessary, and long ago, have done for our American what the German and French entomologists have done for the European species.

The writer, who so long ago as I 864 , published the first clue to the solution of the mystery of agamic reproduction in the family of the cynipidae, has, unfortunately, grown old without finding the leisure to follow, very far, the fascinating field for discovery that then appeared before him.

I have, since then, done some fragmentary work in the way of describing new species, and some work that I do not yet despair of giving to the world in the shape of a monograph of the cyni- pidae, but the limited leisure I have had and the uncertainty of being able to follow to results, any investigations or observations that demanded attention at a definite time and place, has debarred me from following what I still think, one of the most interesting and important branches of entomological study.

I have gathered a few facts, however, and I beg to lay before the readers of Psyche an account of a discovery I made this last spring, partly in the hope that it may lead some one to go further in the same line,-but chiefly, because every discovery in science belongs to the world just as soon as its validity is established.

One of our most common gall insects here in Connecticut is Callirhytis futilis, O. S. The galls appear in early summer, in great numbers on the leaves of 2uercus alba. They are in the form of conical blotches, projecting from both surfaces of the leaf, but are more prom- 
inent on the upper surface, and are about one-fourth of an inch in diameter. Each gall produces three of four small gall-flies that emerge about the first of July, copulating immediately and then disappearing. Where they went nobody knew, or seemed to know till I found out their secret last spring.

Before the leaves appeared I visited a thicket of young oaks where I had found these galls very abundant in past years, hoping to find their progenitorwhoever she might be-ovipositing in the buds of these oaks-but I was too early; she had not begun her work. But where was she napping at the time? This question was not by any means a new one to me.

The soft, sandy loam at the roots of a clump of oak bushes,-softer because of the effects of the frost that had but recently left it,-yielded to my fingers and I soon had one of the main roots laid bare. Judge of the joyful surprise it gave me to find the bark of this root a solid mass of blister like swellings.

Removing a portion of it with my knife I found it literally full of minute larvae, each imbedded in a mass of liv. ing vegetable pulp, but so very small and immature were these larvae that I was certain that they could not arrive at maturity in season for egg-laying in the then swelling buds.

I uncovered other roots of this and other clumps of oaks, always finding more or less of the larvae in the bark, and at length, in some older blisters, I found well grown cynipidous larvae, evidently a year older than those first found, but still their maturity seemed too far off for the work to be done within the next few days.

I collected on that and several close succeeding days a quantity of bark containing larvae, and, placing it in sand, and in a glass case, found after three or four days that several perfect gall-flies had come out. Within a week or so quite a number appeared, but the bark deprived of the sap of the tree, no longer furnished food for the young larvae and they died.

That nature, provident against the extinction of her children, in this case, keeps two generations in the larval state at the same time seems absolutely certain, and I feel nearly sure there are really three; that the larger larvae noticed will not appear until next spring, and that the perfect insects were in that state at the time I first found the galls.

But I am asked: How do you know that these root gall-flies are the producers of the futilis galls? Perhaps I cannot convince the querist, but the proof I have to offer is as follows :

Suffering in health from too close confinement in my place of business during the winter, as soon as the weather would permit, I spent a part of nearly every pleasant day in the open air. I improved these hours in watching my pets in the woods and thickets. I found hundreds of gall-flies ovipositing in the buds of oaks of various species, flies of several species, and one of these I found abundant on the low white oak bushes. I captured many of them but left unmolested far more than I cap 
tured, marking the trees and the very twigs on which they were at work. Waiting till the leaves were fully grown I found these oaks bore futilis galls in abundance, but no other species, and comparing the flies I captured with those I got from the bark galls found them to be identical. Of their identity there can be no doubt whatever.

But I am asked: Do they agree in character with the flies from the futilis galls? They do not; and they would, no doubt, be described as a different species. They are many times larger than the futilis flies, and there are other points of difference. But this variation was to be looked for, developed, as the two generations are, under conditions so widely different.

Dr. Adler and other European entomologists, who have followed the life history of these insects more closely than I have been able to do, have found that the two generations differ so widely that they have been classed, by those who were not aware of their close relationship, not only as two different species, but have actually been placed in different genera.

I name and describe this insect as follows :

Callirhytis radicis, Bass. (agamous form of $N$. futilis, O. S.) Head black and opaque, face, cheeks and vertex with short, bristle-like hairs. Antennae very short, with fourteen distinct joints; the first joint short and thick, the second globular (scarcely ovate) ; length of the third one-fourth less than that of the two preceeding, the diameter of each from the eighth to the fourteenth inclusive equals their length; the last forms a very blunt cone. Color of the antennae dark reddish brown, changing gradually to a dull dusky brown towards the apex.

'Thorax black, the punctuation fine and beautifully regular and even. Parapsidal grooves extending throughout, broad, shining lines over the base of the wings, a narrow but distinct median line from the collare to the scutellum and two parallel lines, one each side or the median line and in close proximity to it, reaching half way from the collare to the scutellum.

Scutellum coarsely and irregularly wrinkled, the fovae round, deep and shining.

Abdomen large, black with brown translucent edges; second segment very long and with a dense band of yellowish white hairs on the anterior margin, the third segment mostly, and the remaining ones quite concealed.

Legs: trochanter black, the remaining joints very dark cinnamon brown. Claws black, simple. Wings large, hyaline; principal veins pale brown, others colorless; radial area broad, the angle of the first transverse vein projecting sharply into the basal portion; areolet very small and the lateral veins bounding it entirely colorless.

Length: body, .I5; antennae, 09; wings, . . 6 .

Those taken in the act of ovipositing are in all respects like those described except that the color of the antennae, legs and wings is a trifle darker,--owing, 
no doubt, to the fact that these were exposed to the sunlight while the others were not.

Females reared from futilis galls this season are .10 in length; the wings . Io and the antennæ .07 with thirteen joints only, with a partial suture on one side of the terminal joint.

The median line on the thorax entirely wanting; the head less hairy but with a few scattered hairs on the thorax and on the sides of the second abdominal segment. The wing-veins are a darker brown.

The galls are blister-like swellings in the smooth bark of the roots of young white oak trees, completely covering the root in some cases for the distance of two feet or more from the tree.

Note.-A later examination of these insects in a strong light shows that the head and abdomen are really a very dark reddish brown. In ordinary reflected light they are easily taken for black.

\title{
ON A NEW SPECIES OF PEDIOPSIS.
}

\author{
BY EDWARD P. VAN DUZEE, BUFFALO, N. Y.
}

To the kindness of Mr. D. W. Coquillett of Los Angeles, California, I am indebted for the opportunity of examining a very interesting lot of Fassidae from that locality. Among this material is one insect that deserves special notice. It is a species of Pediopsis closely allied to the eastern viridis, and still more closely to the European virescens. The colors are probably somewhat faded and possibly altered by an alcoholic bath, but this will scarcely affect the determination of the species. It may be characterized as follows :

Pediopsis occidentalis n. $\mathrm{sp}$.

Female.-Form of P. viridis, broader and more robust than $P$. virescens. Color dull greenish yellow, uniform; propleura with a black spot; antennal seta brown. Length about $5 \mathrm{~mm}$.
Face as in virescens, more distinctly punctured than in viridis; front broader below at the base of the clypeus, which is proportionately narrower, and the lorae are much more tumid than in that species or virescens; the clypeus is broadly depressed entirely across the apex, while in viridis this depression is confined to the narrow submargin on either side before the lora, and is scarcely more extended than in the European species. Antennae pale at base, setae brownish. Pronotum shorter and broader than in either of the allied species; the rugae are less distinct than in virescens, but more so than in viridis. Propleura with a black spot. Ventral plate as in virescens, shorter and broader toward the apex than in viridis, the tip emarginate, and the sides distinctly con- 

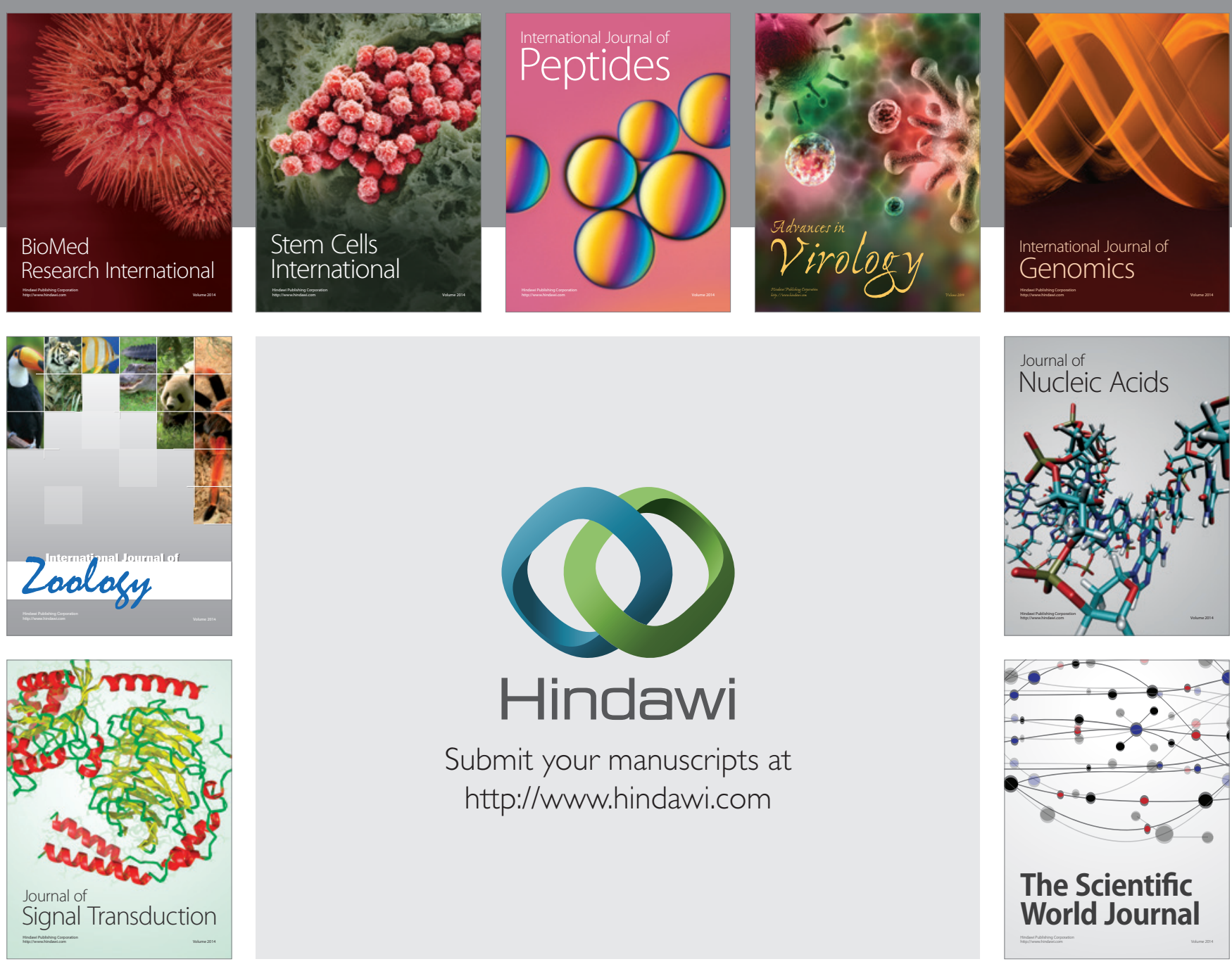

Submit your manuscripts at

http://www.hindawi.com
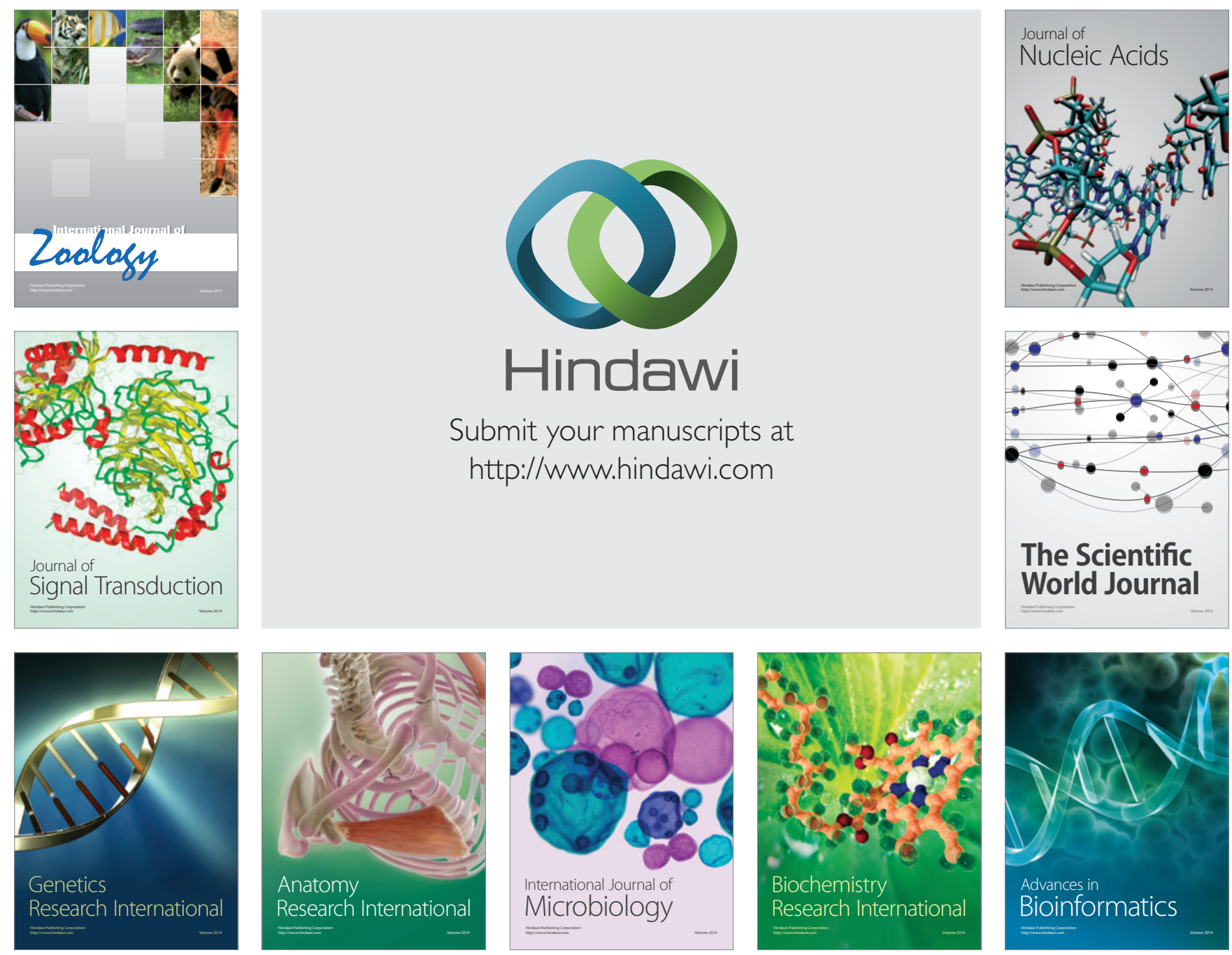

The Scientific World Journal
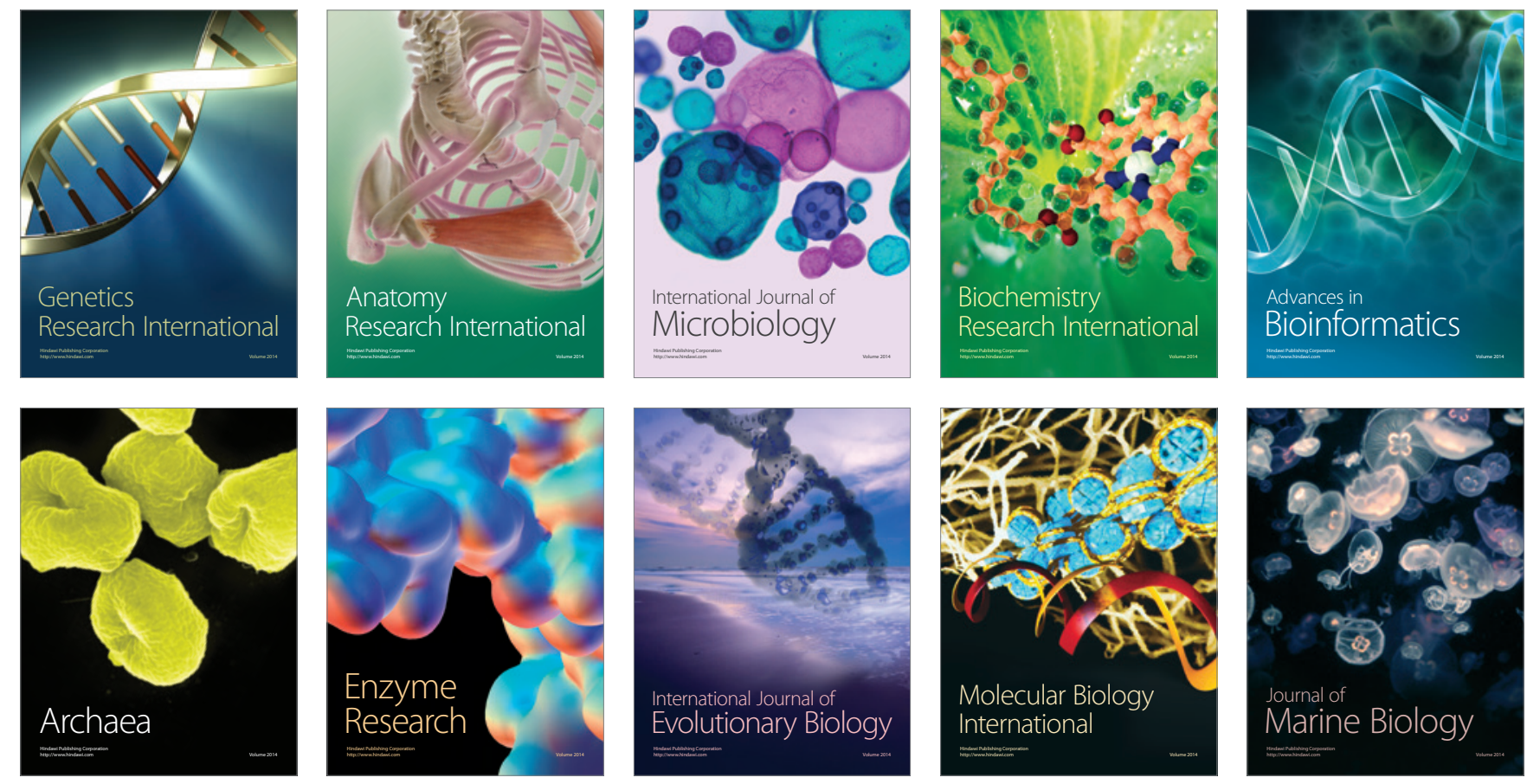